\title{
Performance of Summer Sesame (Sesamum indicum L.) under Various Irrigation Schedules and Weed Management Practices
}

\author{
P.P. Mallick, M.R. Satapathy*, S.K. Samantaray and R.R. Pattnaik \\ Department of Agronomy, College of Agriculture, OUAT, \\ Bhubaneswar-751003, Odisha, India \\ *Corresponding author
}

\begin{tabular}{l} 
Ke y w o r d s \\
$\begin{array}{l}\text { Irrigation } \\
\text { scheduling, Weed } \\
\text { management } \\
\text { practices, } \\
\text { Consumptive use } \\
\text { and Water use } \\
\text { efficiency }\end{array}$ \\
\hline $\begin{array}{l}\text { Article Info } \\
\text { Accepted: } \\
\text { 22 June } 2020 \\
\text { Available Online: } \\
\text { 10 July } 2020\end{array}$ \\
\hline
\end{tabular}

\section{A B S T R A C T}

A field experiment was conducted during summer season of 2015 at the Agronomy Main Research Farm, Odisha University of Agriculture and Technology, Bhubaneswar to study the "Performance of summer sesame (Sesamum indicum L.) under various irrigation schedules and weed management practices" .The experiment was laid out in a split-plot design with 3 replications comprising of 3 irrigation schedules in the main plot (IW/CPE $=0.8,1.0$ and 1.2) and 4 weed management practices in the sub -plot (W1 - Weedy check,W2 - Two hand weeding at 21 and 42 DAS,W3 - Pre-emergence application of pendimethalin@ $0.75 \mathrm{~kg} / \mathrm{ha}+1 \mathrm{HW}$ at $42 \mathrm{DAS}, \mathrm{W} 4$ - Post-emergence application of quizalofop ethyl @ $0.05 \mathrm{~kg} / \mathrm{ha}+1 \mathrm{HW}$ at 42 DAS). The sesame variety "Prachi" was used as test variety. The crop was sown on 25.02.2015 and harvested on 22.05.2015. The soil of the experimental site was sandy loam in texture, acidic in reaction with medium organic carbon $(0.68 \%)$, and available $\mathrm{N}(263.5 \mathrm{~kg} / \mathrm{ha})$, available $\mathrm{P}_{2} \mathrm{O}_{5}(10.6 \mathrm{~kg} / \mathrm{ha})$ and available $\mathrm{K}_{2} \mathrm{O}(108.6 \mathrm{~kg} / \mathrm{ha})$. The moisture content at field capacity and permanent wilting point were $21.6 \%$ and $11.8 \%$ respectively. The experimental results revealed that irrigating the sesame crop at IW/CPE ratio of 1.0 recorded the highest seed yield of $835 \mathrm{~kg} / \mathrm{ha}$ which was at par with IW/CPE ratio of $1.2(765 \mathrm{~kg} / \mathrm{ha})$. Among the weed management practices, pre-emergence application of pendimethalin @ $0.75 \mathrm{~kg} / \mathrm{ha}+1 \mathrm{HW}$ at 42 DAS recorded the highest seed yield of $1009 \mathrm{~kg} / \mathrm{ha}$ followed by two hand weeding at 21 and 42 DAS $(833 \mathrm{~kg} / \mathrm{ha})$. Similar trend was also observed in yield parameters, stalk yield and oil yield. Maximum consumptive use of water by the crop was noticed at IW/CPE ratio of 1.2 (59.8 $\mathrm{cm})$ and in pre-emergence application of pendimethalin @ $0.75 \mathrm{~kg} / \mathrm{ha}+1 \mathrm{HW}(56.0 \mathrm{~cm})$.But the water use efficiency was found to be maximum $(17.78 \mathrm{~kg} / \mathrm{ha} \mathrm{cm})$ at IW/CPE ratio of 0.8 followed by 1.0 and 1.2 respectively and among weed management practices, at preemergence application of pendimethalin @ 0.75kg/ha+1 HW $(18.02 \mathrm{~kg} / \mathrm{ha} \mathrm{cm})$.

\section{Introduction}

The oilseed scenario in India has undergone a dramatic change in last 20 years with the setting up of Technology Mission on Oilseeds (TMO) in May, 1986.India became nearly self-sufficient in edible oils by 1991 due to lunching of TMO, and after that oilseed production has virtually declined. In India, oilseed follows cereals, sharing $14 \%$ of the Gross Cropped Area, 3\% of the Gross Domestic Product and $5.98 \%$ value of all 
agricultural commodities (2014-15). Despite being the largest cultivator of oilseeds in the world, India imports about $50 \%$ of its requirements owing to the life style changes in dietary pattern and increasing per capita income. India is the world's largest producer of sesame and stand first in both area and production but productivity is low. India is the 4th largest edible oil economy in the world. It contributes $10 \%$ to the global oilseed production, of which it contributes only 6-7\% for global vegetable oil production. In India, sesame is cultivated over an area of 19.81 lakh ha with the production of 8.87 lakh tonnes during 2015-16.Sesame is one of the drought tolerant crops in the world. But it needs adequate moisture for its establishment. Irrigation scheduling plays an important role in the higher production of summer sesame. Tripathy and Bastia (2012) observed that IW/CPE ratio of 1.0 resulted higher seed and oil yield in summer sesame with net return of Rs. 4258 /-ha. It is also necessary to concentrate more on weeding out the undesirables than for any other activity related to increasing agricultural production.

Keeping these points in view, a field experiment entitled "Performance of summer sesame (Sesamum indicum L.) under various irrigation schedules and weed management practices" was conducted at Agronomy Main Research Station, OUAT, Bhubaneswar to study the effect of irrigation schedules and weed management practices on growth and yield of summer sesame and to assess the consumptive use and water use efficiency under various treatments.

\section{Materials and Methods}

A field experiment was conducted during summer season of 2015 at the Agronomy Main Research Farm, Odisha University of Agriculture and Technology, Bhubaneswar to study the "Performance of summer sesame
(Sesamum indicum L.) under various irrigation schedules and weed management practices". The experiment was laid out in a split-plot design with 3 replications comprising of 3 irrigation schedules in the main plot (IW/CPE $=0.8,1.0$ and 1.2) and 4 weed management practices in the sub -plot $\left(\mathrm{W}_{1}-\right.$ Weedy check, $\mathrm{W}_{2}$ - Hand weeding at 21 and 42 DAS, $W_{3}$ - Pre-emergence application of pendimethalin @ $0.75 \mathrm{~kg} / \mathrm{ha}+1 \mathrm{HW}$ at 42 DAS, $\mathrm{W}_{4}$ - Post-emergence application of quizalofop ethyl @ $0.05 \mathrm{~kg} / \mathrm{ha}+1 \mathrm{HW}$ at 42 DAS). The sesame variety "Prachi" was used as test variety. The soil of the experimental site was sandy loam in texture, acidic in reaction with medium organic carbon $(0.68 \%)$, and available $\mathrm{N} \quad(263.5 \mathrm{~kg} / \mathrm{ha})$, available $\mathrm{P}_{2} \mathrm{O}_{5}(10.6 \mathrm{~kg} / \mathrm{ha})$ and available $\mathrm{K}_{2} \mathrm{O}(108.6 \mathrm{~kg} / \mathrm{ha})$. The moisture content at field capacity and permanent wilting point were $21.6 \%$ and $11.8 \%$ respectively. The crop was sown on 25-02-2015 and harvested on 22-05-2015. The recommended fertilizer dose of sesame 60:30:30 Kg N: $\mathrm{P}_{2} \mathrm{O}_{5}: \mathrm{K}_{2} \mathrm{O} /$ ha was used in the experiment. Full quantity of $\mathrm{P}_{2} \mathrm{O}_{5}, \mathrm{~K}_{2} \mathrm{O}$ and half of $\mathrm{N}$ fertilizer were applied as basal at the time of final land preparation and rest of half $\mathrm{N}$ fertilizer was top dressed at 30 DAS. The source of N, P205 and K20 fertilizers were urea, DAP and MOP, respectively. Well decomposed farm yard manure@ @ 5.0 t/ha was applied during final land preparation and was mixed thoroughly with soil. Scheduling of irrigation was done on the basis of the ratio of irrigation water depth (IW) to cumulative pan evaporation (CPE) values recorded from USWB class-A open pan evaporimeter maintained at the crop observatory of OUAT, Bhubaneswar. A fixed quantity of $50 \mathrm{~mm}$ of water with the help of a $7.5 \mathrm{~cm}$ parshall flume was applied at each irrigation. The CPE values were adjusted for the effective rainfall received during irrigation intervals. Initially one irrigation was given on the day following sowing to facilitate uniform germination of seeds. Another common 
irrigation was given 10 days after for sustenance of the crop. The consumptive use of water by the crop under different treatments was worked out using the formula described by Dastane (1972).The crop water use efficiency (WUE) was calculated by the following formula and was expressed as $\mathrm{kg}$ seed per ha-cm of water used.

WUE = yield $(\mathrm{Kg} / \mathrm{ha}) /$ consumptive use of water $(\mathrm{cm})$

The experimental data obtained for various characters under the study were analysed statistically by applying analysis of variance (ANOVA) technique as described by Gomez and Gomez (1984).The level of significance used in $\mathrm{F}$ test was given at $5 \%$. Test of significance between treatments were compared using critical difference (CD) at 5\% level of probability $(\mathrm{P}=0.05)$.

\section{Results and Discussion}

\section{Yield attributes}

Data on yield attributes in Table revealed that irrigating the crop at IW/CPE ratio of 1.0 recorded the corresponding increase in number of capsules per plant, number of seeds per capsule, length of capsule and test weight of seeds, and ultimately higher seed yield, stalk yield and oil yield of sesame than IW/CPE ratio of 1.2 and 0.8 . This proved the necessity of optimal irrigation in sesame crop, which resulted in higher yield attributing characters and yield. The crop irrigated at IW/CPE ratio of 1.0 registered the highest harvest index value of $26.12 \%$, but the irrigation level did not exhibit any significant influence on the partitioning of photosynthates towards the reproductive part.

Different weed control methods significantly influenced yield attributing characters. The yield attributing characters like number of capsules per plant, number of seeds per capsule and 1000-seed weight was significantly more in IW/CPE ratio of 1.0 than 1.2 and 0.8 ratio. This was due to the fact that favourable plant water balance maintained through irrigation might have resulted in better translocation of photosynthates and maintenance of cell turgidity, consequently leading to higher yield traits. Similar finding was reported by Tripathy and Bastia (2012) and Saren et al., (2005).

Highest number of capsules/ plant and number of seeds per capsule were obtained at irrigating the crop at IW/CPE ratio of 1.0 irrespective of weed management treatments because of better growth of the crop due to less crop weed competition at higher irrigation level. The length of capsule and test weight did not vary significantly due to interaction effect of irrigation and weed management practices. Gradual higher length of capsules was observed when all weed management practices were combined with IW/CPE ratio of 1.0 .

\section{Yield}

Maximum seed, biological and oil yield was recorded for IW/CPE ratio of 1.0.Further increase in IW/CPE ratio to 1.2 resulted in slight decline in seed yield, biological yield and significant decrease in oil yield. These results are in conformity with the findings of Tripathy and Bastia (2012).

Among weed management practices, preemergence application of pendimethalin @ $0.75 \mathrm{~kg} / \mathrm{ha}+1 \mathrm{HW}$ at 42 DAS recorded maximum seed, oil and biological yield, followed by two hand weeding at 21 and 42 DAS. This might be due to lower crop weed competition which ultimately enhanced the seed yield, biological yield and in turn oil yield. The minimum oil yield was recorded against weedy check. 
Table.1 Effect of irrigation \& weed management practices on yield attributes, yield, consumptive use and WUE of summer sesame

\begin{tabular}{|c|c|c|c|c|c|c|c|c|c|c|c|}
\hline Treatments & $\begin{array}{c}\text { No.of } \\
\text { capsules/ } \\
\text { plant }\end{array}$ & $\begin{array}{l}\text { Length } \\
\text { of } \\
\text { capsule } \\
(\mathrm{cm})\end{array}$ & $\begin{array}{c}\text { No.of } \\
\text { seeds/ } \\
\text { capsule }\end{array}$ & $\begin{array}{c}1000 \\
\text { seed } \\
\text { weight } \\
(\mathrm{g})\end{array}$ & $\begin{array}{c}\text { Seed } \\
\text { yield } \\
\text { (kg/ha) }\end{array}$ & $\begin{array}{c}\text { Stalk } \\
\text { yield } \\
\text { (kg/ha) }\end{array}$ & $\begin{array}{c}\text { Harvest } \\
\text { index } \\
(\%)\end{array}$ & $\begin{array}{c}\text { Oil } \\
\text { content } \\
(\%)\end{array}$ & $\begin{array}{l}\text { Oil yield } \\
\text { (kg/ha) }\end{array}$ & $\begin{array}{l}\text { Consum- } \\
\text { ptive } \\
\text { use }(\mathrm{cm})\end{array}$ & $\begin{array}{c}\text { Water use } \\
\text { efficiency } \\
\text { (kg/ha- } \\
\text { cm) }\end{array}$ \\
\hline \multicolumn{12}{|l|}{ Irrigation schedules $($ IW/CPE $)=3$} \\
\hline$I_{1}=0.8$ & 37.54 & 2.17 & 51.83 & 3.03 & 685 & 1859 & 26.45 & 39.58 & 274 & 38.4 & 17.83 \\
\hline$I_{2}=1.0$ & 43.68 & 2.61 & 58.75 & 3.29 & 835 & 2296 & 26.12 & 43.33 & 365 & 54.0 & 15.46 \\
\hline$I_{3}=1.2$ & 41.10 & 2.37 & 56.50 & 3.13 & 765 & 2171 & 25.45 & 41.25 & 318 & 59.8 & 12.79 \\
\hline $\operatorname{SEm}( \pm)$ & 1.023 & 0.05 & 0.97 & 0.09 & 20.11 & 59.00 & 0.64 & 1.84 & 15.20 & - & - \\
\hline $\mathrm{CD}(\mathrm{P}=0.05)$ & 4.01 & 0.23 & 3.81 & NS & 78.94 & 231.59 & NS & NS & 59.66 & - & - \\
\hline \multicolumn{12}{|l|}{ Weed management practices $=4$} \\
\hline $\mathrm{W}_{1}-$ Control (Weedy check) & 22.62 & 1.80 & 45.78 & 3.00 & 406 & 1728 & 19.28 & 39.89 & 162 & 43.2 & 9.39 \\
\hline $\mathrm{W}_{2}-\mathrm{Two}$ hand weeding at 21 and $42 \mathrm{DAS}$. & 43.41 & 2.54 & 59.11 & 3.16 & 833 & 2174 & 27.68 & 41.44 & 348 & 53.6 & 15.54 \\
\hline $\begin{array}{l}W_{3}-\text { Pre-emergence application of pendimethalin @ } \\
0.75 \mathrm{~kg} / \mathrm{ha}+1 \mathrm{HW} \text { at } 42 \mathrm{DAS}\end{array}$ & 55.62 & 2.85 & 62.00 & 3.38 & 1009 & 2393 & 29.78 & 43.56 & 439 & 56.0 & 18.01 \\
\hline $\begin{array}{l}\text { W }_{4} \text {-Post-emergence application of quizalofop ethyl @ } \\
0.05 \mathrm{~kg} / \mathrm{ha}+1 \mathrm{HW} 42 \text { DAS }\end{array}$ & 41.44 & 2.35 & 55.89 & 3.06 & 799 & 2139 & 27.29 & 40.67 & 327 & 51.0 & 15.66 \\
\hline $\operatorname{SEm}( \pm)$ & 1.09 & 0.06 & 0.94 & 0.07 & 20.57 & 63.02 & 0.90 & 1.27 & 14.60 & - & - \\
\hline $\mathrm{CD}(\mathrm{P}=0.05)$ & 3.23 & 0.19 & 2.81 & NS & 61.13 & 187.23 & 2.68 & NS & 43.38 & - & - \\
\hline \multicolumn{12}{|l|}{$\mathbf{I} \times \mathbf{W}$} \\
\hline $\operatorname{SEm}( \pm)$ & 2.22 & 0.13 & 1.99 & 0.19 & 42.54 & 128.67 & 1.73 & 3.06 & 30.7 & - & - \\
\hline $\mathrm{CD}(\mathrm{P}=\mathbf{0 . 0 5})$ & 7.21 & NS & 6.51 & NS & 138.48 & NS & 5.45 & NS & NS & - & - \\
\hline
\end{tabular}


The interaction effect of various irrigation schedules and weed management practices on stalk yield, oil content and oil yield was found to be non-significant.

\section{Consumptive use (CU)}

Different irrigation schedules and weed management practices showed marked variation in consumptive use of water by sesame. The consumptive use increased from $38.4 \mathrm{~cm}$ to $59.8 \mathrm{~cm}$ with an increase in frequency of irrigation. Frequent application of irrigation at IW/CPE ratio of 1.2 increased the $\mathrm{CU}$ to $59.8 \mathrm{~cm}$ which decreased gradually with subsequent decrease in IW/CPE to the minimum of $38.4 \mathrm{~cm}$ at IW/CPE ratio of 0.8.There was decrease in $\mathrm{CU}$ at IW/CPE of 1.0 and 0.8 as compared to 1.2. The different weed management practices also showed variation in consumptive use The consumptive use of water ranged from $43.2 \mathrm{~cm}$ to $56.0 \mathrm{~cm}$ due to various weed management practices.CU of water by the crop was maximum (56.0) at pre-emergence application of pendimethalin @ $0.75 \mathrm{~kg} / \mathrm{ha}+1$ HW followed by two hand weeding at 21 and 42 DAS (53.6) and post-emergence application of quizalofop ethyl @ $0.05 \mathrm{~kg} / \mathrm{ha}$ +1 HW (51.0).

\section{Water use efficiency (WUE)}

Increase in frequency of irrigation with increasing IW/CPE ratios progressively decreased the WUE. Maximum WUE of $17.83 \mathrm{~kg} / \mathrm{ha}-\mathrm{cm}$ was observed at IW/CPE ratio of 0.8 , which was higher than IW/CPE of 1.0 and 1.2. Irrigating the crop at IW/CPE ratio of 1.0 had higher WUE than that of 1.2 ratio. The water use efficiency (WUE) was maximum $(18.01 \mathrm{~kg} / \mathrm{ha}-\mathrm{cm})$ when sesame crop was managed with pre-emergence application of pendimethalin @ $0.75 \mathrm{~kg} / \mathrm{ha}+$ 1 HW followed by post-emergence application of quizalofop ethyl @ 0.05kg/ha
$+1 \mathrm{HW}(15.66 \mathrm{~kg} / \mathrm{ha}-\mathrm{cm})$ and two HW at 21 and 42 DAS (15.54 kg/ha-cm).The water use efficiency was minimum $(9.39 \mathrm{~kg} / \mathrm{ha}-\mathrm{cm})$ in weedy check plots.

It can be concluded from the present study that Scheduling irrigation at IW/CPE ratio of 1.0 performed better than IW/CPE ratio of 0.8 and 1.2 to use in sesame crop. Pre-emergence application of pendimethalin @ $0.75 \mathrm{~kg} / \mathrm{ha}+1$ HW at 42 DAS can be used for weed management in sesame as the treatment has higher weed control efficiency than other treatments. Scheduling irrigation at IW/CPE ratio of 1.0 in combination with preemergence application of pendimethalin @ $0.75 \mathrm{~kg} / \mathrm{ha}+1 \mathrm{HW}$ at $42 \mathrm{DAS}$ is the most productive and remunerative approach for increasing yield of summer sesame in our state.

\section{References}

Dastane NG. 1972. Practical manual for wateruse research in agriculture, Navbharat Prakashan, Pune, Maharastra.p.129.

Gomez KA and Gomez AA. 1984. Statistical procedures for agricultural research. Second Edition. An International Rice Research Institute Book.AwileyInterscience Publication, John Wiley and sons, New York.

Mathukia RK, Sagarka BK and Jadav CN. 2015.Integrated weed management in summer sesame, Indian Journal of Weed Science, 47(2): 150-152.

Saren BK, Nandi P and Tudu S. 2005. Effect of irrigation and sulphur on yield attributes and yield, oil content and oil yield and consumptive use efficiency of summer sesame, Journal of Oilseed Research ,22:383-384.

Tripathy S and Bastia DK. 2012. Irrigation and nutrient management for yield augmentation of summer sesame (Sesamum indicum L.), Journal of Crop and Weed, 8(2): 53-57. 


\section{How to cite this article:}

Mallick, P.P., M.R. Satapathy, S.K. Samantaray and Pattnaik, R.R. 2020. Performance of Summer Sesame (Sesamum indicum L.) under Various Irrigation Schedules and Weed Management Practices. Int.J.Curr.Microbiol.App.Sci. 9(07): 3662-3667.

doi: https://doi.org/10.20546/ijcmas.2020.907.429 